\title{
THE STUDENTS’ ANXIETY TOWARD ENGLISH LEARNING
}

\author{
Siti Rodiah ${ }^{1}$, Neneng Islamiah ${ }^{2}$ \\ Islamic University of Kalimantan \\ nislamiah@gmail.com
}

\begin{abstract}
Nowadays in Indonesia, English has been taught at school from the various levels. English is the first foreign language that becomes one of compulsory subject in Final Examination (UN). MacIntyre \& Gardner (1993:284). The result of the highest and the lowest percentage of students' preference in FLCAS questionnaire. The researcher found that $66,7 \%$ respondents give the highest response "Strongly Agree" to statement number 5 (I start to panic when I have to speak without preparation in language class). While $11,1 \%$ respondents give the lowest response "Strongly Agree" to the statement number 7 (I feel confident when. I speak in foreign language class). The result of this research show that most of the students are at "Anxious" level students. There are 21 (78\%) students who experience "Anxious" level, 5 (19\%) students are in "Mildly Anxious" level, and only 1 (4\%) student from 27 students, is in "Relaxed" level. Keywords: English Learning Achievement, Students' Anxiety
\end{abstract}

\section{INTRODUCTION}

The success of mastering foreign language can be said when people are capable to carry out the conversation at ease. Therefore the students must enhance their speaking ability along with the other skills. But then, to speak in foreign languages students certainly will experience various obstacles. The obstacles can be the difficulties of mastering grammar, the lack of vocabulary mastery, and problems in pronunciation and fluency.

Beside the grammatical problems, the students also get the barrier from psychological aspect such as self-esteem, motivation, and anxiety. Among them, anxiety is an important facet on the affective domain (Balemir, 2009:26). The students tend to feel shy and not confident in speaking foreign language especially English.

According to Horwitz and Cope (1986:162-163) language anxiety is a distinct complex of self-perceptions, feeling and behaviors related to classroom language learning process. 
THE STUDENTS' ANXIETY TOWARD ENGLISH LEARNING

Siti Rodiah ${ }^{1}$, Neneng Islamiah ${ }^{2}$

MacIntyre \& Gardner (1993:284) define language anxiety as the feeling of tension and apprehension specifically associated with second language context including speaking, listening, and learning. Anxiety is a situation where the students feel anxious, shy, and afraid to make mistake in speaking in front of the class. Anxiety will give negative influence toward students' behaviors. The lack of courage in speaking will definitely impede students to get success in foreign language classroom.

Anxiety can be classified as trait anxiety, situation-specific anxiety, and state anxiety. Trait anxiety can be relatively stable in individuality trait; a student who have anxious trait is possibly feel anxious in a variety of condition. Situation-specific anxiety occurs in specific type of situation or event such as public speaking, test-taking, or class participation. On the other hand, state anxiety is occurs temporarily at particular situation. Further, many previous researches have been revealed some factors that causes language anxiety. It can be from students' self-perception, social environment, cultural differences, social status, gender, and classroom environment (Tseng, 2012:75-90). Those researches indicate that anxiety has an enervating effect on language learning process.

By those all of anxiety factors, learning a foreign language seem quite difficult for students. Thus, based on the problem identification above the researcher wants to analyze the level of students' anxiety toward their learning English Achievement at The Eighth Grade of SMP Negeri 30 Banjarmasin school year 2018/2019.

\section{METHODOLOGY}

This research used a descriptive quantitave. According to Neil A. Weiss (2012:31) Descriptive statistics consists of methods for organizing and summarizing information. The researcher wanted to find out whether the students have a significant influence between the students' English learning achievement and the students' anxiety level, especially for the students at the eighth grade of SMP Negeri 30 Banjarmasin school year 2018/2019. The researcher is going to use the instrument is questionnaire in collecting the data. A questionnaire, according to Amanda Hunn et al (2009:9) questionnaires are a useful option to consider when conducting a postal survey.

FLCAS questionnaire used to gain the data from the respondents and to measure students' level of anxiety in language class. This close-ended questionnaire presented in form of Likert's scale, which is consist of 5-1 options of answer. This scale provided five responses ranging from "Strongly Agree" (SA)", “Agree (A)", "Neither Agree nor Disagree (NA)", 
"Disagree (D)", and "Strongly Disagree (SD)". The researcher calculated each point of each statement to get the total score of students' anxiety. The lowest score is 20 , and the highest score is 45 . The highest of the total score, means that the respondent is getting more anxious.

\section{FINDINGS}

The most positive answers are given score 1, 2, 3, 4, 5 and most negative score 5, 4, 3, 2 , 1. After the questionnaires were collected, the data were tabulated. The researcher analyzed the questionnaires and to find out the result of frequency in descriptive statistical analysis, the formula used was:

$$
f=\frac{\text { number of each option }}{N} X 100 \%
$$

\section{Statement 1}

I never feel quite sure of myself when I am speaking in my foreign language class

Table 1

\begin{tabular}{|l|r|r|r|r|}
\hline & Frequency & Percent & $\begin{array}{c}\text { Valid } \\
\text { Percent }\end{array}$ & $\begin{array}{c}\text { Cumulative } \\
\text { Percent }\end{array}$ \\
\hline Valid SA & 15 & 55,6 & 55,6 & 55,6 \\
A & 10 & 37,0 & 37,0 & 92,6 \\
D & 2 & 7,4 & 7,4 & 100,0 \\
Total & 27 & 100,0 & 100,0 & \\
\hline
\end{tabular}

Based on the table that the student's choose $55,6 \%$ for strongly agree, $37,0 \%$ for agree, $0 \%$ for neither agree and nor disagree, $7,4 \%$ for disagree, $0 \%$ for strongly disagree. It means that most of the student's never feel quite sure when speaking in foreign language class. Then, statement has the highest score "strongly agree" 55, 6\% for communication apprehension.

\section{Statement 2}

I don't worry about making mistakes in language class

Table 2 
THE STUDENTS' ANXIETY TOWARD ENGLISH LEARNING

Siti Rodiah ${ }^{1}$, Neneng Islamiah ${ }^{2}$

\begin{tabular}{|l|r|r|r|r|}
\hline & Frequency & Percent & $\begin{array}{c}\text { Valid } \\
\text { Percent }\end{array}$ & $\begin{array}{c}\text { Cumulative } \\
\text { Percent }\end{array}$ \\
\hline Valid SA & 12 & 44,4 & 44,4 & 44,4 \\
A & 8 & 29,6 & 29,6 & 74,1 \\
N & 3 & 11,1 & 11,1 & 85,2 \\
D & 4 & 14,8 & 14,8 & 100,0 \\
Total & 27 & 100,0 & 100,0 & \\
\hline
\end{tabular}

Based on the table that the student's choose $44,4 \%$ for strongly agree, $29,6 \%$ for agree, $11,1 \%$ for neither agree and nor disagree, $14,8 \%$ for disagree, $0 \%$ for strongly disagree. It means that most of the student's not worry about making mistakes in language class. Then, statement has the highest score "strongly agree" 44, 4\% for related to anxiety in English learning process.

\section{Statement 3}

I tremble when I know that I'm going to be called on in language class

Table 3

\begin{tabular}{|r|r|r|r|r|}
\hline & Frequency & Percent & $\begin{array}{c}\text { Valid } \\
\text { Percent }\end{array}$ & $\begin{array}{c}\text { Cumulative } \\
\text { Percent }\end{array}$ \\
\hline Valid SA & 14 & 51,9 & 51,9 & 51,9 \\
A & 11 & 40,7 & 40,7 & 92,6 \\
N & 1 & 3,7 & 3,7 & 96,3 \\
D & 1 & 3,7 & 3,7 & 100,0 \\
Total & 27 & 100,0 & 100,0 & \\
\hline
\end{tabular}

Based on the table that the student's choose $51,9 \%$ for strongly agree, $40,7 \%$ for agree, 3,7\% for neither agree and nor disagree, 3,7\% for disagree, $0 \%$ for strongly disagree. It means that most of the student's tremble when know to be called on in language class. Thus, statement has highest score $51,9 \%$ for strongly agree is related to fear of negative evaluation.

\section{Statement 4}

I keep thinking that the other students are better at languages than I am 
Table 4

October 2019. Vol 2 No.2

\begin{tabular}{|c|r|r|r|r|}
\hline & Frequency & Percent & $\begin{array}{c}\text { Valid } \\
\text { Percent }\end{array}$ & $\begin{array}{c}\text { Cumulative } \\
\text { Percent }\end{array}$ \\
\hline Valid SA & 9 & 33,3 & 33,3 & 33,3 \\
A & 11 & 40,7 & 40,7 & 74,1 \\
N & 3 & 11,1 & 11,1 & 85,2 \\
D & 3 & 11,1 & 11,1 & 96,3 \\
SD & 1 & 3,7 & 3,7 & 100,0 \\
Total & 27 & 100,0 & 100,0 & \\
\hline
\end{tabular}

Based on the table that the student's choose 33, 3\% for strongly agree, 40, 7\% for agree, $11,1 \%$ for neither agree and nor disagree, $11,1 \%$ for disagree, $3,7 \%$ for strongly disagree. It means that most of the student's keep thinking that the other students are better at language than them. Thus, statement has the highest score $40,7 \%$ for "agree" is related to fear of negative evaluation.

\section{Statement 5}

I start to panic when I have to speak without preparation in language class

Table 5

\begin{tabular}{|l|r|r|r|r|}
\hline & Frequency & Percent & $\begin{array}{c}\text { Valid } \\
\text { Percent }\end{array}$ & $\begin{array}{c}\text { Cumulative } \\
\text { Percent }\end{array}$ \\
\hline Valid SA & 18 & 66,7 & 66,7 & 66,7 \\
A & 9 & 33,3 & 33,3 & 100,0 \\
Total & 27 & 100,0 & 100,0 & \\
\hline
\end{tabular}

Based on the table that the student's choose $66,7 \%$ for strongly agree, $33,3 \%$ for agree, $0 \%$ for neither agree and nor disagree, $0 \%$ for disagree, $0 \%$ for strongly disagree. It means that most of the student's start to panic when they have to speak without preparation in language

class. Then, statement has the highest $66,7 \%$ for strongly agree is communication apprehension in English learning process.

\section{Statement 6}


THE STUDENTS' ANXIETY TOWARD ENGLISH LEARNING

Siti Rodiah ${ }^{1}$, Neneng Islamiah ${ }^{2}$

I often feel like not going to my language class

Table 6

\begin{tabular}{|l|r|r|r|r|}
\hline & Frequency & Percent & $\begin{array}{c}\text { Valid } \\
\text { Percent }\end{array}$ & $\begin{array}{c}\text { Cumulative } \\
\text { Percent }\end{array}$ \\
\hline Valid SA & 1 & 3,7 & 3,7 & 3,7 \\
A & 8 & 29,6 & 29,6 & 33,3 \\
N & 13 & 48,1 & 48,1 & 81,5 \\
D & 5 & 18,5 & 18,5 & 100,0 \\
Total & 27 & 100,0 & 100,0 & \\
\hline
\end{tabular}

Based on the table that the student's choose 3, 7\% for strongly agree, 29, 6\% for agree, $48,1 \%$ for neither agree and nor disagree, $18,5 \%$ for disagree, $0 \%$ for strongly disagree. It means that most of the student's often feel like not going to language class, has statement the highest $48,1 \%$ for neither agree and nor disagree.

\begin{tabular}{|c|c|c|c|c|}
\hline & Frequency & Percent & Valid Percent & $\begin{array}{c}\text { Cumulative } \\
\text { Percent }\end{array}$ \\
\hline Vali SA & 3 & 11,1 & 11,1 & 11,1 \\
\hline A & 5 & 18,5 & 18,5 & 29,6 \\
\hline $\mathrm{N}$ & 6 & 22,2 & 22,2 & 51,9 \\
\hline D & 10 & 37,0 & 37,0 & 88,9 \\
\hline SD & 3 & 11,1 & 11,1 & 100,0 \\
\hline Total & 27 & 100,0 & 100,0 & \\
\hline
\end{tabular}

Table 7 I feel confident when I speak in foreign language class

Based on the table that the student's choose $11,1 \%$ for strongly agree, $18,5 \%$ for agree, $22,2 \%$ for neither agree and nor disagree, $37,0 \%$ for disagree, $11,1 \%$ for strongly disagree. It means that most of the student's feel confident when speak in foreign language class has the highest score $37,0 \%$ for disagree that statement.

\section{Statement 8}




\section{INTENSIVE JOURNAL}

http://ojs.uniska-bjm.ac.id/index.php/EJB

E-ISSN 1513567470

October 2019, Vol 2 No.2

When I'm on my way to language class, I feel very sure and relaxed

Table 8

\begin{tabular}{|r|r|r|r|r|}
\hline & Frequency & Percent & $\begin{array}{c}\text { Valid } \\
\text { Percent }\end{array}$ & $\begin{array}{c}\text { Cumulative } \\
\text { Percent }\end{array}$ \\
\hline Valid SA & 1 & 3,7 & 3,7 & 3,7 \\
A & 7 & 25,9 & 25,9 & 29,6 \\
N & 14 & 51,9 & 51,9 & 81,5 \\
D & 5 & 18,5 & 18,5 & 100,0 \\
Total & 27 & 100,0 & 100,0 & \\
\hline
\end{tabular}

Based on the table that the student's choose 3, 7\% for strongly agree, 25, 9\% for agree, $51,9 \%$ for neither agree and nor disagree, $18,5 \%$ for disagree, $0 \%$ for strongly disagree. It means that most of the student's feel very sure and relaxed to English learning process. Thus, the statement has highest score $51,9 \%$ for neither agree and nor disagree.

Table 8

\begin{tabular}{|c|r|r|r|r|}
\hline & Frequency & Percent & $\begin{array}{c}\text { Valid } \\
\text { Percent }\end{array}$ & $\begin{array}{c}\text { Cumulative } \\
\text { Percent }\end{array}$ \\
\hline Valid SA & 5 & 18,5 & 18,5 & 18,5 \\
A & 13 & 48,1 & 48,1 & 66,7 \\
N & 4 & 14,8 & 14,8 & 81,5 \\
D & 4 & 14,8 & 14,8 & 96,3 \\
SD & 1 & 3,7 & 3,7 & 100,0 \\
Total & 27 & 100,0 & 100,0 & \\
\hline
\end{tabular}

Based on the table that the student's choose $18,5 \%$ for strongly agree, $48,1 \%$ for agree, $14,8 \%$ for neither agree and nor disagree, $14,8 \%$ for disagree, $3,7 \%$ for strongly disagree. Thus, 
THE STUDENTS' ANXIETY TOWARD ENGLISH LEARNING

Siti Rodiah ${ }^{1}$, Neneng Islamiah ${ }^{2}$

statement has highest score $48,1 \%$ for agree and the students related to fear of negative evaluation.

\section{Statement 10}

I get nervous when the language teacher ask questions which I haven't prepared in advance

Table 10

\begin{tabular}{|c|r|r|r|r|}
\hline & Frequency & Percent & $\begin{array}{c}\text { Valid } \\
\text { Percent }\end{array}$ & \multicolumn{1}{c|}{$\begin{array}{c}\text { Cumulative } \\
\text { Percent }\end{array}$} \\
\hline Valid SA & 12 & 44,4 & 44,4 & 44,4 \\
A & 14 & 51,9 & 51,9 & 96,3 \\
N & 1 & 3,7 & 3,7 & 100,0 \\
Total & 27 & 100,0 & 100,0 & \\
\hline
\end{tabular}

Based on the table that the student's choose 44, 4\% for strongly agree, 51, 9\% for agree, $3,7 \%$ for neither agree and nor disagree, $0 \%$ for disagree, $0 \%$ for strongly disagree. It means that most of the student's choose agree with that statement. Thus, the highest score is $51,9 \%$ students related to anxiety toward English learning.

The result show that the highest and the lowest percentage of students' preference in FLCAS questionnaire. The researcher found that $66,7 \%$ respondents give the highest response "Strongly Agree" to statement number 5 (I start to panic when I have to speak without preparation in language class). While $11,1 \%$ respondents give the lowest response "Strongly Agree" to the statement number 7 (I feel confident when. I speak in foreign language class).

Based on 10 items of statement in FLCAS questionnaire, there were varieties of responses from the all respondents. The researcher found out that, there were 27 students who had different levels of anxiety in toward English learning achievement. (1) There were 21 students (29\%) who experience "Anxious" level, and the range score for "Anxious" level started from 36-40. (2) There were 5 students (19\%) are in "Mildly Anxious" level, it means a half of the respondents are in range score 31-35. (3) There were 1 students (4\%) that had "Relaxed" level, and the range score of this level is started from 26-30. It means that many students have problem in reducing anxiety. Only 1 students are in low level of anxiety (relaxed). In this discussion section, the researcher admits that she did not figure out the influence of students' anxiety level toward English learning achievement. The researcher also calculates the data using SPSS program and manually. These students had best level to face 
anxiety when they are performing English. Later on, the researcher also shows the lowest score in each level of anxiety in the following table.

Table 11

\begin{tabular}{|c|c|c|}
\hline Level of Anxiety & Name code & Score \\
\hline Mildly Anxious & RT & 32 \\
Relaxed & RR & 30 \\
\hline
\end{tabular}

The researcher show high anxiety will impede students in learning foreign language such as Young (1986) and Aida (1994). In this study, the researcher found that students with high anxiety, from the total of 27 respondents, 21 students $(78 \%)$ experience the "Anxious" level and the most of the respondents are in the normal level of anxiety. It can be seen from table above, although these students are having anxiety feeling. The researcher found that in this case, anxious feeling might not occur when they are performing in foreign language.

Later on, more a half of the students (19\%) are in the level of mildly anxious. It can be a normal condition when many people are also feeling tense or nervous when they have to perform something in front of other people especially teacher.

Meanwhile, there are only student which in the level of "Relaxed" and he score in satisfactory and excellent category. It means, he no problem with anxiety level. He has low stress level, so that English learning achievement good.

\section{CONCLUSION}

Based on the data analysis and the result of study, it can conclude that the result of this research show the most of the students who are "Anxious" level is $78 \%$ students, $19 \%$ students are in "Mildly anxious" level, those are from the 27 students. Although these students on the eighth grade of SMP Negeri 30 Banjarmasin school year 2018/2019 are having anxiety feeling. It can be a normal condition when many people are also feeling tense or nervous when they have to perform something in front of other people especially teacher.

\section{REFERENCES}

Aida, Y. 1994. Examination of Horwitz, Horwitz and Cope's Construct 
Siti Rodiah ${ }^{1}$, Neneng Islamiah ${ }^{2}$

of Foreign Language Anxiety: The Case of Students in Japan. The Modern Language Journal, Vol. 78, No.2, p. 155-168, June 1994. Retrieved from: http://libgen.org/scimag/get.php?doi=10.1111\%2Fj.15404781.1994.tb02026.x

Brown, H.D. 2001. Principle of language learning and teaching. Beijing: Foreign Language Teaching and Research Press.

Cheng, Y., Horwitz., E.K., \&. Schaller, D.L. 1999. Language Anxiety: Differentiating Writing and Speaking Components. Language Learning, 49(3), 417-446.

Gardner, R.C. \& MacIntyre, P.D. 1993. A Student's Contributions to Second Language Learning. Part II: Affective Variables. Language Teaching Vol. 26. (pp 1-11). Pretoria: University of South Africa.

Hunn, Amanda et al 2009. Surveys and. Questionnaires. Sheffield:. The. NIHR RDS EM/YH

Horwitz, E. K., Horwitz, M. B., and Cope, J. 1986. Foreign language classroom anxiety. The Modern Language Journal, 70(2), 125- 132.

Horwitz, E.K. 2001. Language Anxiety and Achievement Annual Review of Applied Linguistics, 21, 112-126.

MacIntyre, P. D., \& Gardner, R. C. 1989. Anxiety and Second Language Learning: Toward a Theoretical Clarification. Language Learning, Vol 39, 251-275.

MacIntyre, P.D. 1999. Language Anxiety: A review of the research for language teachers. In D. J. Young (Ed.), Affect in foreign language and second language learning (pp. 2245). Boston: McGraw-Hill.

Marwan, A. 2007. Investigating Students' Foreign Language Anxiety. Malaysian Journal of ELT Research, 3, 37-55.

Mayangta, T. 2013. Students' Speaking Anxiety in an EFL Classroom. Research Paper, Universitas Pendidikan Indonesia.

McMillan, J. H. 2008. Educational Research: Fundamentals for the Customer. Boston, M. A.: Pearson Education Inc.

Northrup, David. 2013. How English Became the Global Language. Palgrave Macmillan. ISBN 978-1-137-30306-6. Retrieved 25 March 2019. Lay summary (25 March 2019).

Setiyadi,A. B. 2006. Research Methodologies for Foreign Language Teaching: Quantitative and Qualitative Approaches. Yogyakarta: Graha Ilmu.

Spielberger, C.D. 1983. Manual for the State-Trait Anxiety (From Y) Consulting Psychologists Press, Palo Alto, CA (1983)

Tseng, S. 2012. The Factors Cause Language Anxiety. WHAMPOA - An Interdisciplinary Journal Vol 63. (pp75-90). 


\section{INTENSIVE JOURNAL}

http://ojs.uniska-bjm.ac.id/index.php/EJB

E-ISSN 1513567470

October 2019, Vol 2 No.2

Wahyuni, E. S. 2015. Students' Anxiety in the Speaking Class and its Consequences toward their Speaking Achievement (A Case Study of the Eighth Grade Students of Bilingual Program at SMP Islam Al Azhar 21 Solo. Baru) SebelasMaret University.

Young, Dolly. Jesuta (ED.). 1999. Affect in Foreign Language and Second Language Learning: a Practical Guide to Creating a Low-Anxiety Classroom Atmosphere. Boston: McGrawHill College

Zuckerman, M., Charles D. S., 2015. Emotion and. Anxiety: New Concepts, Methods, and Aplication. Part 1. New. York:. Psychology. Press pp:179-91

Zhao, N. 2007. A study of high school students' English learning anxiety. The Asian EFL Journal. 9.3, 22-34. 